\title{
STUDI PENERAPAN SEMA NO. 1 TAHUN 2017 DI PENGADILAN AGAMA TALU
}

\author{
Elimartati \\ Institut Agama Islam Negeri Batusangkar \\ Email: elimartati@iainbatusangkar.ac.id \\ Firdaus \\ Institut Agama Islam Negeri Batusangkar \\ Email: almuqaddas12@gmail.com
}

\author{
Ahmad Julio Saputra \\ Institut Agama Islam Negeri Batusangkar \\ DOI: 10.37876/adhki.v2i2. $\underline{30}$
}

\begin{abstract}
The Supreme Court Circular No. 1 of 2017 aims to provide legal protection for women's rights after divorce. But in its implementation women's rights are neglected. Wives are often in an attenuated position. The problem in this paper is between the expectations and challenges of the execution of the living in the pronunciation of the divorce pledge no. 121/Pdt.G/2018/PA TALU which is not carried out by the husband. The research method uses a gender analysis approach. Data is collected based on observations, interviews and documents. The findings in this study are three conditions in which all three cannot provide justice to women's rights. First; the husband does not execute the judge's decision on the obligation of living set by the judge of the Talu Religious Court, the pledge of divorce cannot be carried out, the marriage remains valid but the husband and wife are not home anymore and the wife never again earns a living. Second; If the sincere wife does not get her rights after the divorce, then the judge can witness the divorce pledge of the husband finally occurs divorce. Third; when the research was done the husband had done siri marriage. Women become psychologically and materially victimized in the absence of efforts to seek justice (dead ends). The best solution is to expect the husband's awareness of his responsibility to provide a living which is his obligation, will be accounted for before Allah SWT. In certain circumstances divorce is the best solution so that both regardless of the burden of birth and mental suffering, do not cause greater mafsadah. SEMA's goal of protecting the rights of wives is not in fact also achieved.
\end{abstract}

Keywords: Execution, Living, Gender, Verdict

Abstrak
Surat Edaran Mahkamah Agung No 1 Tahun 2017 bertujuan untuk memberikan perlindungan
hukum bagi hak-hak perempuan pasca perceraian. Namun dalam pelaksanaannya hak-hak
perempuan terabaikan. Istri sering di posisi yang terlemahkan. Permasalahan dalam tulisan
ini antara harapan dan tantangan pelaksanaan eksekusi nafkah dalam pengucapan ikrar talak
perkara Nomor 121/Pdt.G/2018/PA TALU yang tidak dijalankan oleh suami. Metode
penelitian memakai pendekatan analisis gender. Data dikumpulkan berdasarkan observasi,
wawancara dan dokumen. Temuan dalam penelitian ini ada tiga kondisi yang ketiganya tidak
dapat memberikan keadilan terhadap hak-hak perempuan. Pertama; suami tidak
mengeksekusi putusan hakim tentang kewajiban nafkah yang ditetapkan oleh hakim
Pengadilan Agama Talu, ikrar talak tidak dapat dilaksanakan, perkawinan tetap sah tetapi
suami-istri tidak serumah lagi dan istri tidak pernah lagi mendapatkan nafkah. Kedua; bila


istri ikhlas tidak mendapatkan hak-haknya setelah perceraian, maka hakim dapat menyaksikan ikrar talak suami akhirnya terjadi perceraian. Ketiga; saat penelitian dilakukan suami telah melakukan nikah siri. Perempuan menjadi korban secara psikis dan materi dengan tidak adanya upaya untuk mencari keadilan (jalan buntu). Solusi yang terbaik adalah mengharapkan kesadaran suami akan tanggung jawabnya memberikan nafkah yang merupakan kewajibannya, akan dipertanggungjawabkan di hadapan Allah SWT. Dalam kondisi tertentu perceraian menjadi solusi terbaik agar keduanya terlepas dari beban penderitaan lahir dan batin, tidak menimbulkan mafsadah yang lebih besar. tujuan SEMA untuk melindungi hak-hak istri kenyataannya tidak juga tercapai

Kata Kunci: Eksekusi, Nafkah, SEMA, Gender, Putusan

\section{Pendahaluan}

Perkawinan bertujuan untuk membina rumah tangga yang bahagia, sejahtera, dan kekal berdasarkan Ketuhanan Yang Maha Esa. ${ }^{1}$ Pernikahan bukan hanya sekedar hubungan biologis semata antara jenis kelamin yang berbeda sebagaimana makhluk lainnya. ${ }^{2}$ Akan tetapi, proses kehidupan yang terjadi tidak sesuai dengan apa yang diimpikan. Hambatan dan masalah banyak terjadi. Apabila suami dan istri tidak kuat dalam menghadapi masalah rumah tangga, maka jalan yang ditempuh adalah perpisahan yang secara hukum dikenal dengan perceraian. $^{3}$

Perceraian merupakan realitas yang tidak dapat dihindari apabila suamiistri telah mencoba mencari penyelesaian dengan jalan damai atau musyawarah. Jika masih belum terdapat kesepakatan dan merasa tidak bisa melanjutkan keutuhan keluarga maka permasalahan diajukan ke pengadilan untuk dicari jalan keluar yang terbaik. Dalam pengadilan agama, dikenal dengan cerai gugat dan cerai talak. Pengadilan merupakan upaya terakhir untuk mempersatukan kembali suami dan istri yang berniat bercerai tadi dengan jalan membuka lagi pintu perdamaian dengan cara Mediasi memakai penengah yakni mediator. ${ }^{4}$

Akibat perceraian pasal $149 \mathrm{KHI}$, suami memberikan nafkah iddah dan mut'ah kepada istri menjadi wajib ketika telah terjadi perceraian ${ }^{5}$ dan dipertegas oleh SEMA Nomor 1 Tahun 2017, huruf C, angka 1, yang berbunyi: dalam rangka pelaksanaan PERMA Nomor 3 Tahun 2017 tentang pedoman mengadili perkara perempuan berhadapan dengan hukum untuk memberi perlindungan hukum bagi hak-hak perempuan pasca perceraian, maka pembayaran kewajiban akibat perceraian, khususnya nafkah iddah, mut'ah, dan nafkah madliyah, dapat

${ }^{1}$ Presiden Ri dan Menteri/Sekretaris Negara RI, Undang-undang Republik Indonesia Nomor ! Tahun 1974 Tentang Perkawinan (Jakarta Republik Indonesia,1974)

${ }^{2}$ Muhammad Rudi wijaya dan Anas Habibi Ritonga, Istri Sebagai Pencari Nafkah Utama dan Dampaknya dalam Keluarga Perspektif Hukum Islam (Padang Sidempuan: Fitrha Jurnal kajian Ilmu-ilmu Keislaman, Vol 04, 2018), hal. 389

${ }^{3}$ Abdullah Aziz Muhammad Azzam dan Abdullah Wahab Sayeed Hawas, Ushratu wa Ahkamuhu fi altasti' al-Islami, diterjemahkan oleh Abdul Majid Khon, Fikih Munakahat, ( Jakarta, Amzah, 2009), hal.261

4 (PERMA Nomor 01 Tahun 2016

${ }^{5} \mathrm{KHI}$ 
dicantumkan dalam amar putusan dengan kalimat dibayar sebelum pengucapan ikrar talak. Ikrar talak dapat dilaksanakan bila istri tidak keberatan atas suami tidak membayar kewajiban tersebut pada saat itu (ketentuan ini mengubah huruf C, angka 12, SEMA Nomor 3 Tahun 2015, in casu nafkah iddah, mut'ah, dan nafkah madliyah). ${ }^{6}$

Terjadi kasus suami tidak memberikan kewajiban yang ditetapkan hakim dengan alasan tidak memiliki uang, suami tidak mau memberikan nafkah kepada mantan istri, seperti kasus perkara Nomor 121/Pdt.G/2018/PA TALU. Berdasarkan observasi terhadap dua pasang suami dan istri yang telah mengikuti sidang di Pengadilan Agama. Suami menyanggupi membayarkan hak-hak istri dengan cara mencicil kepada mantan istri, sedangkan mantan istri tersebut ingin dibayar dengan lunas, seiring berjalannya waktu hak talak suami gugur setelah enam bulan diputus dan mereka sudah pisah ranjang selama 6 tahun 4 bulan. ${ }^{7}$. Istri: tidak mendapatkan haknya yang diputus oleh pengadilan beralasan penghasilan tidak. $^{8}$ Kasus kedua suami: telah mengikuti persidangan di Pengadilan Agama dan dituntut untuk membayar nafkah, bulan pertama dibayar oleh suami dan pada bulan selanjutnya mantan suami merantau berakhir dengan pisah ranjang. ${ }^{9}$ Istri: mengatakan tidak pernah menerima haknya dan istri tidak pernah bertemu dengan suami, keberadaan suami tidak diketahui ${ }^{10}$, akhirnya suami melakukan nikah siri dengan perempuan lain karena tidak memiliki akta cerai.

Memahami kasus di atas realitanya secara teori SEMA bertujuan untuk melindungi hak-hak istri tetapi kenyataannya hak-hak perempuan sering terabaikan. Istri di posisi yang terlemahkan. bila dibandingkan dengan Peraturan mengenai nafkah iddah talak yang terdapat dalam UU Keluarga Muslim Malaysia dan Yordania masih lebih menjamin hak-hak perempuan pasca perceraian dibandingkan dengan peraturan yang ada di Indonesia. ${ }^{11}$ Cerminan kasus diatas perempuan terpapar antara harapan mendapatkan perlindungan hukum tentang hak-haknya, namun kenyataan di tengah masyarakat pelaksanaan eksekusi nafkah masih menimbulkan tanda Tanya besar. Bagaimana caranya perempuan agar mendapat perlindungan hukum. Mendapat kepastian hukum atas hak dari pembayaran nafkah iddah, mut'ah dan madiyah. Masalah ini membutuhkan pemikiran hukum oleh Hakim, pemerhati hukum baik berupa terobosan hukum atau merupakan hasil ijtihad atas dasar kemaslahatan umat dalam hal ini sebagai sebuah pembaharuan hukum demi menjaga hak-hak perempuan yang selama ini banyak dirugikan.

\footnotetext{
${ }^{6}$ SEMA Nomor 01 Tahun 2017

7 (S wawancara, Talu 18 Juli 2018).

8 (E, wawancara, Talu 18 Juli 2018).

${ }^{9}$ (J, wawancara, Talu18 Juli 2018)

${ }^{10}$ (S, wawancara, Talu 18 Juli 2018)

11 ( Hammad, Al-Ahwal, Vol. 7, No. 1, 2014 M/1435 H)
} 


\section{Metode Penelitian}

Tulisan ini berdasarkan data hukum normatif, pendekatan masalah memakai metode kualitatif dengan analisis gender. Teknik pengumpulan data, pertama observasi dengan mengamati kondisi dan keadaan rumah tangga suamiistri yang bermasalah. Kedua wawancara dilakukan kepada tiga orang hakim yang memutus perkara pelaksanaan eksekusi nafkah dalam pengucapan ikrar talak perkara Nomor 121/Pdt.G/2018/PA TALU dan Suami yang tidak mau membayarkan nafkah pasca ikrar talak, beserta Istri yang tidak mendapatkan nafkah dari Suami dengan menggunakan wawancara yang tidak berstruktur hanya pedoman wawancara sebagai alat bantu agar masalah penelitian tetap berada pada jalur yang sudah dibatasi. Pelaksanaan wawancara memakai alat bantu buku catatan yang berfungsi untuk mencatat semua percakapan dengan sumber data, tape recorder untuk merekam percakapan dan kamera untuk mendokumentasikan peristiwa atau keadaan kondisi sedang wawancara. Analisis data dilakukan sebelum mengambil data di lapangan sebelum penelitian dan sesudah penelitian dengan menggunakan proses berkesinambungan, kemudian data diverifikasi untuk menarik kesimpulan data yang dianalisis dan menentukan temuan penelitian beserta analisisnya. Melengkapi permasalahan penelitian dan data sekunder berbentuk putusan perkara Nomor 121/Pdt.G/2018/PA TALU dan SEMA Nomor 1 Tahun 2017.

\section{Gambaran Kasus Perkara Nomor 121/Pdt.G/2018/Pa Talu Dan Data Penelitian}

Pengadilan Agama Talu yang memeriksa dan mengadili Cerai Talak antara: Darmis bin Darias, sebagai Pemohon Konvensi/Tergugat Rekonvensi. Melawan, Rita. S binti Siatin, Termohon Konvensi/ Penggugat Rekonvensi. permohonannya tertanggal 08 Maret 2018 mengajukan permohonan Cerai Talak didaftar di Pengadilan Agama Talu dengan Nomor 121/Pdt.G/2018/PA TALU, Bahwa pemohon dan termohon sudah menikah sesuai dengan Duplikat Buku Nikah Nomor: 187/46/111/2008, tinggal bersama membina rumah tangga di rumah orang tua Termohon, dari perkawinan telah dikaruniai anak bernama Nadya Shafwah, lahir pada tanggal 11 Mei 2010. Sejak pertengahan tahun 2009, rumah tangga Pemohon dan sering terjadi perselisihan dan pertengkaran yang disebabkan masalah ekonomi rumah tangga. tanggal 25 Oktober 2011 Pemohon pergi dari kediaman bersama. Telah terjadi pisah ranjang selama 6 (enam) tahun 4 (empat) bulan dan selama itu istri tidak pernah diberi nafkah oleh suaminya.

Hakim melihat fakta-fakta, alat bukti dan keterangan saksi yang terjadi di persidangan, hakim mempertimbangkan: kondisi suami bekerja sebagai penjahit pakaian dan mempunyai pekerjaan tetap maka hakim mempertimbangkan kondisi suami. Berdasarkan ungkapan dari bapak Afrizal, S.Ag., M.Ag ketua Pengadilan Agam Talu, perceraian antara suami istri dianggap terjadi beserta 
akibat hukumnya terhitung sejak jatuhnya putusan Pengadilan Agama Talu ${ }^{12}$ adapun akibat hukumnya adalah:

a. Memberikan mut'ah

b. Memberikan nafkah selama mantan istri menjalani masa iddahnya.

c. Pelunasan mahar, bila mahar istri terhutang baik sebagian maupun seluruhnya dan istri belum disetubuhi maka wajib bagi suami melunasinya kecuali istri telah merelakannya.

d. Memberi biaya hadhanah bagi anak-anaknya yang belum dewasa, anakanak yang belum mencapai umur 21 tahun masih menjadi tanggung jawab dari ayahnya.

e. Pelunasan nafkah selama dalam masa perkawinan.

Dalam penetapan ikrar talak hakim berpedoman kepada SEMA Nomor 1 Tahun 2017, sesuai dengan amar putusan perkara Nomor 121/Pdt.G/2018/PA TALU mengadili:

Dalam konvensi

a. Mengabulkan permohonan Pemohon Konvensi.

b. Memberi izin kepada Pemohon Konvensi (Darmis bin Darias) untuk menjatuhkan talak satu raj'i terhadap Termohon Konvensi (Rita. S binti Siatin) di depan sidang Pengadilan Agama Talu.

Dalam Rekonvensi

a. Mengabulkan gugatan Penggugat Rekonvensi sebagian.

b. Menghukum Tergugat Rekonvensi untuk memberikan hak-hak Penggugat Rekonvensi berupa:

a. Nafkah madhiyah Penggugat Rekonvensi untuk seluruhnya sejumlah Rp6.000.000 (enam juta rupiah).

b. Nafkah selama masa iddah Penggugat Rekonvensi sejumlah Rp3.000.000 (tiga juta rupiah).

Putusan

a. Menetapkan anak Penggugat Rekonvensi dan Tergugat Rekonvensi yang bernama Nadya Shafwah, lahir pada tanggal 11 Mei 2010 di bawah hadhanah Penggugat Rekonvensi.

b. Menghukum Tergugat Rekonvensi untuk memberikan nafkah anak Penggugat Rekonvensi dan Tergugat Rekonvensi setiap bulannya sampai anak tersebut dewasa dan mandiri (berumur 21 tahun) sejumlah Rp750.000 (tujuh ratus lima puluh ribu rupiah) melalui Penggugat Rekonvensi.

c. Menghukum Tergugat Rekonvensi untuk membayar kewajiban sebagaimana tercantum dalam angka dua dan empat amar putusan ini sebelum ikrar talak diucapkan.

d. Menolak gugatan Penggugat Rekonvensi untuk selebihnya

${ }^{12}$ Afrizal, S.Ag., M.Ag (Pada hari Kamis 22 November ketua Pengadilan Agam Talu) 
Hasil observasi, peneliti mengamati kondisi rumah tangga pemohon dan termohon sudah lama berpisah, artinya sudah pisah ranjang. Setelah terjadi persidangan rumah tangga mereka semakin tidak menentu, status perkawinan tidak jelas.

\section{Pandangan Hakim Pengadilan Agama Talu terhadap SEMA No. 1 Tahun 2017}

SEMA ini hanya berlaku sesaat sebelum ikrar talak diucapkan, hakim bisa menilai hal seperti itu, nanti yang laki laki ini tidak memenuhi perkataannya, sehingga sema nomor 1 tahun 2017 ini di tekankan sekali untuk melindungi perempuan. Setelah keluar sema nomor 1 tahun 2017, jika laki-laki tidak mampu membayarkan kewajibannya, apa yang terjadi.? jika dalam jangka waktu 6 bulan tidak dibayarkan, maka mereka akan kembali menjadi suami istri lagi. Apabila tidak ingin kembali bersama dan kewajiban juga tidak terbayarkan apa yang akan terjadi.? jika istri sudah izin, maka talak tetap dilanjutkan, namun hak istri tetap terabaikan. pelaksanaan eksekusi nafkah Tahapan nya yaitu: Orang yang akan dieksekusi ini mampu atau tidak, kemudian di pertimbangkan, kemudian di jelaskan hak hak atas istrinya. pertimbangan hakim terhadap putusan nafkah yang belum dibayarkan menasehati laki-laki dengan pertimbangan keagamaan, masukan moral . Bila laki-laki tidak menjalankan kewajibannya kami juga tidak bisa memaksakan, cuma kami memberikan pandangan dan arahan, nasehat kepada dia akan kewajibannya sebagai seorang suami, menanamkan nilai keagamaan. Menentukan nafkah iddah, hakim menetapkan nafkah berdasarkan kemampuan suami suami dan dihubungkan dengan kondisi perekonomian yang ada di daerah itu

\section{Studi terhadap Putusan Pengadilan}

\section{Dari perspektif suami}

Saya bekerja tukang jahit, Saya menghabiskan hari-hari saya disini (ruko) tempat saya menjahit, disinilah cara saya untuk mempertahankan hidup saya. Apakah Bapak sudah menjalani Putusan Pengadilan? jawabnya belum. Apakah Bapak berniat untuk melaksanakan isi Putusan Pengadilan?, kalua berniat pasti, tapi karena tuntutan nafkah yang diputus pengadilan terlalu besar, mau bagaimana saya memberikan uang sebanyak itu Apa yang melatarbelakangi Bapak belum melaksanakan isi Putusan?, saya tidak sanggup mengumpulkan uang sebanyak itu, saya pun sudah mengatakan kepada hakim saya hanya sanggup membayar nafkah iddah 1.500 .000 setelah istri saya menuntut nafkah iddah setiap bulan 5.000.000, dan hakim memutuskan 3.000.000 dan nafkah madiyah dituntut istri saya 5.000 .000 setiap tahun, tapi kesanggupan saya 5.000.000 seluruhnya dan hakim memutuskan 6.000.000. Bagaimana perasaan Bapak belum melaksanakan isi Putusan tersebut?

Informan 4 Masalah perasaan saya belum melaksanakan isi putusan, ya mau bagaimana lagi kan kesanggupan saya sudah saya katakana. Kapan bapak ingin 
melaksanakan isi Putusan tersebut? Jauh hari pun saya ingin melaksanakan kalua yang dituntut itu sesuai kesanggupan saya. Apa yang dilakukan ketika mantan Istri meminta hak Nafkah? Saya katakan kalau saya belum mempunyai uang. Bagaimana tindak lanjut terhadap Istri yang akan Bapak Talak itu? Menurut saya sudah bercerai, dan kami sudah lama berpisah, dan untuk memenuhi kewajiban, ya sudah berlalu.

2. Dari perspektif Istri

Kenapa Ibu belum menerima Nafkah yang telah diputus oleh Pengadilan? karena suami saya belum memberikan nya, saya sudah sering minta ke tempat jahit dia. tetapi dia bilang dia tidak mempunyai uang, memang dia tidak bertanggung jawab, saya sedih hak saya tidak dikasih, yang saya minta hanya, 5.000 .000 setiap tahun selama kami pisah, bagi laki-laki yang bertanggung jawab pasti segitu tidak sulit. Bagaimana tindak lanjut terhadap Nafkah yang belum Ibu terima? Saya pernah terniat untuk melapor ke pengadilan agama lagi, tapi tetangga saya bilang kalau melaporkan lagi membayar, mahal pula, ya tidak jadi saya laporkan, saya turut ke tempat dia saja pak.

\section{Review Literatur}

Membaca berbagai literatur terkait masalah penelitian dapat mengelompokkan, literatur-literatur yang ada ke dalam empat kecenderungan. Pertama, literatur berbicara tentang suami wajib memberi nafkah kepada istri dan anaknya (keluarga), Kedua, hukum dan akibat hukum yang ditimbulkan karena suami tidak memberikan nafkah kepada istri dan anak-anaknya. ketiga, Akibat hukum dari perceraian, dan keempat konsep nikah siri.

Pertama, literatur berbicara tentang suami wajib memberi nafkah kepada istri dan anaknya (keluarga). Hukum membayar nafkah untuk istri, baik dalam bentuk perbelanjaan, pakaian, tempat tinggal adalah merupakan kewajiban suami yang terukur bentuk, jenis dan kadarnya (muhaddad). ${ }^{13}$ Penyebab yang mewajibkan suami menafkahi istrinya.Ulama Hanafiyah berpendapat karena suami berhak menahan istrinya untuk tidak keluar rumah ataupun bekerja setelah melakukan akad nikah yang sah. ${ }^{14}$. Dasar kewajiban nafkah oleh suami untuk istrinya terdapat dalam al-Quran maupun Hadis Rasulullah SAW. Dalil dalam bentuk al-Quran diantaranya surat al-Baqarah (2: 233). Para fuqaha sepakat akan wajibnya)

Kedua, hukum dan akibat hukum yang ditimbulkan karena suami tidak memberikan nafkah kepada anak-anaknya. menurut Hanafiyah jika suami menolak memberikan nafkah kepada istrinya, dapat dilihat dalam dua kondisi ${ }^{15}$. Pertama, Suami yang menolak memberi nafkah kepada istri punya kemampuan

\footnotetext{
${ }^{13}$ Anita Marwing, Perlindungan Hak-Hak Perempuan Pasca Perceraian (Studi Terhadap Putusan Pengadilan Agama Pelopo), (Pelita: Jurnal of Soscial-Religiresearch Vol.1 No.1), hal 45-62

${ }^{14}$ Wahbah a-Zuhaili Figh a-Islamy wa Adilatuhu, ( Damaskus: Dar al-Fikr, 1989)

${ }^{15}$ Wahbah al-Zuhaili, Ibid, hal. 811
} 
untuk menafkahinya, dan punya benda berharga yang layak dijual maka hakim berhak menjualnya dengan paksa, hasilnya diberikan kepada istri sebagai nafkah. Akan tetapi, jika tidak punya benda berharga yang bisa dijual, namun suami termasuk orang mampu maka hakim berhak menahan atau memenjarakan suami berdasarkan gugatan istri. Pendapat ini berdasarkan Hadis Rasulullah SAW dari Abu Hurairah Riwayat Muslim ${ }^{16}$ Satria Efendi mengungkapkan bahwa kelalaian seseorang untuk memberikan nafkah kepada pihak yang wajib dinafkahinya adalah suatu kejahatan apabila kelalaiannya itu telah menimbulkan mudharat pada diri orang yang wajib dinafkahi. Maka ia disamping dituntut untuk mengganti nafkah, juga diancam dengan hukuman ta' zir, $^{17}$ Kelalaian suami tidak memberikan nafkah pada keluarganya, sehingga istri dan anaknya terlantar, adalah merupakan pelanggaran dan dapat dikatakan kejahatan. ${ }^{18} \mathrm{Hal}$ ini termasuk Kekerasan Dalam Rumah Tangga yakni penelantaran anggota rumah tangga dan mempunyai ancaman hukuman penjara paling lama 3 tahun atau denda paling banyak Rp 15.000.000; (lima belas juta rupiah) di Indonesia.${ }^{19}$ Suami kaya yang tidak mau membayar nafkah itu dipenjara selama ia belum membayar nafkah yang menjadi kewajibannya. Akan tetapi bila keadaan ekonomi suami itu tidak memungkinkan (tidak punya kemampuan) untuk membayar nafkah pada istrinya, maka hakim boleh memberikan keringanan berdasarkan Firman Allah dalam surat al-Baqarah (2: 280)

\section{Tiga, Akibat hukum dari perceraian}

Banyak perceraian disebabkan oleh laki-laki yang melalaikan tanggung jawab nafkah dengan meninggalkan istri dan anakya. Istri berusaha sendiri menafkahi diri dan anak yang ditinggalkan. ${ }^{20}$ Perlindungan hukum bagi perempuan dan anak menjelaskan bahwa nafkah madhiyah dalam kasus perceraian, hak-hak perempuan dan anak terbukti tidak terlindungi. ${ }^{21}$. Hal ini disebabkan karena beberapa faktor, pertama dasar atau alasan hakim memutuskan tuntutan nafkah yang dilalaikan oleh suami tidak memiliki daya paksa (sanksi) untuk memaksa suami menunaikan kewajiban nafkah. Sebagaimana ungkapan hadis di atas.

\footnotetext{
${ }^{16}$ Muslim bin al-Hajaj bin Muslim al-Qusyairy al-Naisabury, Shahih Muslim, (Cairo: Mathba 'ah al-B Problematika Hukum Keluarga Islam Kontemporer,(Jakarta: Kencana, 2004), hlm. 145ulaq, 1290 H), jilid V, hlm. 34

${ }^{17}$ Satria Efendi Problematika Hukum Keluarga Islam Kontemporer,(Jakarta: Kencana, 2004), hlm. 145

${ }^{18}$ Jumni Nelli, Analisis Tentang Kewajiban Nafkah Keluarga dalam pemberlakuan harta Bersama, ( STAIN Curup Bengkulu: Jurnal Istimbat: Jurnal Hukum Islam vol. 2 No.1, 2017) hal. 35

${ }^{19}$ Undang-Undang No 23 Tahun 2004 tentang Penghapusan KDRT Pasal 9 dan Pasal 49

${ }^{20}$ Muhammad Ridwansyah, Nafkah Anak Luar kawin Menurut Konsep Hifzhu al-Nafs (Jural Yudisial Vol.8 No.! April 2015), hal.67, Nunung Rodliyah, Akibat Hukum Perceraian Berdasarkan Undang-Undang Nomor 1 Tahun 1974 Tentang Perkawinan, (Jurnal Keadilan: Volume 5 Nomor 1, 2014), hal 122

${ }^{21}$ Fatimah dkk, Pemenuhan Hak Istri dan Anak Akibat Putusnya Perkawinan Karena Perceraian, (Jurnal Pendidikan Kewarganegaraan: Volume 4, Nomor 7, 20140, hal.562
} 
Kedua, pola ijtihad hakim dalam putusan bersifat pragmatis/menonton., hakim tidak berupaya melindungi hak perempuan, sehingga banyak putusan tentang nafkah tidak dapat direalisasikan, hakim hanya bersifat juru damai (hakam ${ }^{22}$. Pemenuhan hak istri dan anak akibat putusnya perkawinan karena perceraian hasil penelitian menjelaskan bahwa Pemberian mut'ah yang layak kepada mantan istri berbeda-beda dikarenakan sesuai dengan kemampuan suami, majelis hakim menilai tentang kemampuan dari suami. ${ }^{23}$ Hakim tidak mempunyai standar dan ukuran yang dipedomani untuk penetapan kadar mut';ah. Akibat hukum perceraian berdasarkan undang-undang nomor 1 tahun 1974 tentang perkawinan, memaparkan tentang pemeliharaan anak, harta bersama dan terhadap nafkah/biaya istri dan anak. ${ }^{24}$. Pemenuhan nafkah $m u t^{\prime} a h$ iddah, dan madiyah istri sebagai syarat penjatuhan talak dalam peradilan agama di Indonesia ${ }^{25}$ boleh dibayarkan sebelum penjatuhan ikrar talak oleh suami, dengan beberapa pertimbangan maslaha dan ruhsah sehingga apabila diterapkan adalah sah menurut fikih, hal ini dipertegas dalam SEMA No. 01 Tahun 2017.

Empat, Konsep Nikah Siri. Istilah nikah siri lebih populer secara lokal dalam perkawinan di Indonesia. Bila dilihat dalam konsep fikih ada ditemui istilah nikah al-sirri (نكاح السر (Pengertian siri dalam konteks masyarakat di Indonesia dapat dipahami sebagai berikut:

1. Perkawinan yang dipandang sah menurut agama, namun tidak mendaftarkan perkawinannya kepada Kantor Urusan Agama sehingga perkawinan mereka tidak mempunyai legalitas formal dalam hukum positif di Indonesia (UU Perkawinan). ${ }^{26}$ Pengertian seperti ini telah dipergunakan oleh Rasulullah SAW sebagaimana terdapat dalam hadis menyebutkan nikah siri adalah perkawinan yang tidak diiklankan ... dari Ali bin Abi Thalib, bahwasanya Rasulullah SAW ketika lewat bersama para sahabat beliau di bani Zhariq mendengarkan nyanyian dan permainan, maka beliau bertanya, ini ada apa ?. Mereka menjawab pernikahan si fulan ya Rasulullah. Rasulullah berkata sempurna agamanya, inilah nikah, bukan perzinahan dan nikah sirri hingga terdengar gendang dan terlihat asap. Hasan diriwayatkan dari

22 Salma, Elfia dan Afifah Djalal, Perlindunagn Hukum Bagi perempuan dan Anak (Analisis Putusan Hakim Tentang Nafkah Madhiyah pada Pengadilan Agama di Sumatera Barat, (Istimbath, jurnal of Islamic Law /Jurnal Hukum Islam vol 16 No. 16

${ }^{23}$ Fatima, Rabiatul Adawiyah, M.Rifqi, Pemenuhan Hak Istri Dan Anak Akibat Putusnya Perkawinan Karena Perceraian (Studi Kasus Di Pengadilan Agama Banjarmasin), (Jurnal Kewarganegaraan: Volume 4, Nomor 7, 2014), Anita Marwing, Perlindungan Hak-hak Perempuan Pasca Perceraian (Studi Terdadap Putusan Pengadilan Pelopo (Jurnal Pelita: Jurnal of Social-Religi Research: Vol 1 Nomor 1, 2016), hal.48

${ }^{24}$ Nunung Rodliya, Akibat Hukum Perceraian Berdasarkan Undang-Undang Nomor 1 Tahun 1974 Tentang Perkawinan, (Jurnal Keadilan Progresif volume 5 nomor 2014)

${ }^{25}$ Syaiful Hidayat (Jurnal tafaqquh: Jurnal Penelitian dan Kajian Islam Vol 6 Nomor 2, 2018)

${ }^{26}$ Firdaus al-Muqaddas, Pemikiran Satria Efendi M Zein dalam Pembaharuan Hukum Perdata Islam di Indonesia, (Bogor: Landasan Ilmu, 20170, hal. 100 
Umar bin Yahya al-Mazani bahwasanya Rasulullah SAW membenci nikah sirri hingga memukul gendang ${ }^{27}$.

2. Perkawinan yang dilakukan sembunyi-sembunyi oleh laki-laki dan perempuan tanpa diketahui oleh kedua pihak keluarganya sekalipun. ${ }^{28}$ Bahkan benarbenar dirahasiakan sampai tidak diketahui siapa yang menjadi wali dan sanksinya. ${ }^{29}$ Pernikahan seperti dapat dikatakan tidak memenuhi rukun dan syarat perkawinan. dan Umar bin Khatab menganggap pernikahan seperti ini sama dengan zina, sehingga pelakunya boleh dirajam. Dalam hal ini ada atsar riwayat Malik dan al-Bayhagi terjemahannya sebagai berikut Hadis dari Malik dari Abi Zubair al-Makka, bahwasanya Umar bin Khatab dilaporkan kepadanya nikah yang tidak memiliki saksi melainkan seorang laki-laki dan seorang perempuan. Maka Umar berkata ini adalah nikah sirri, tidak akan saya bolehkan. Seandainya lebih dahulu saya ketahui (lalu saya larang namun terus dilakukan) tentu saya telah merajamnya. ${ }^{30}$

Berdasarkan hadis di atas dapat dipahami bahwa Rasulullah membenci nikah siri yang pernikahannya tidak diresmikan, sedangkan Umar melarang nikah siri yang hanya kurang satu orang saksi sehingga pelakunya diancam hukuman rajam. Nikah siri yang sering terjadi di masyarakat dan perkawinannya tidak sah adalah nikah yang tidak dihadiri saksi yang memenuhi syarat secara fikih dan wali nikah berhak sebagai wali.

Pernikahan siri telah melanggar ketentuan pasal 2 ayat (2) UU Perkawinan dan menimbulkan berbagai permasalahan baik kepada suami- istri anak-anaknya. Sebab perkawinan yang sah berakibat pada kewajiban dan hukum-hukum lainnya antara lain hak dan kewajiban suami istri, adanya hubungan hukum ibu-anak, dan ayah-anak, hak dan kewajiban anak-orangtua serta hukum waris. Oleh karena itu pernikahan yang tercatat (sesuai dengan UU No. 1 Tahun 1974 dan PP No. 9 Tahun 1975) sesuai dengan semangat kemaslahatan yang menjadi landasan syariat Islam. ${ }^{31}$ Sebagaimana yang telah diungkapkan oleh ulama ushul fiqh, setiap hukum (syariat) itu terkandung kemaslahatan bagi manusia baik kemaslahatan itu bersifat duniawi maupun ukhrawi. Pandangan sosiologis, nikah siri banyak mengandung persoalan. Oleh sebab itu perlu dihindari karena banyak mudharatnya. pernikahan siri akan merugikan pihak istri dan anak ${ }^{32}$, di antaranya:

1. Istri tidak bisa menggugat suami, apabila ditinggalkan oleh suami. tidak dapat menuntut nafkah yang tidak diberikan oleh suaminya.

\footnotetext{
${ }^{27}$ Sunan Baihaqi bab izhar nikah jilid 7, hal 29

${ }^{28}$ Irfan Islami, Perkawinan di Bawah Tangan (Kawin Sirri) dan Akibat Hukumnya, ( Adil: Jurnal Hukum, Vol.8 No.1), hal.76

${ }^{29}$ M. Thahir Maloko, Nikah Sirri perspektif Hukum Islam ( Sipakalebbi' volume 2, 2014), hal 225

${ }^{30}$ Astsar riwayat Malik dan al-Bayhaqi, muatha'jilid 2, hal 535)

${ }^{31}$ Enik Isnaini, Perkawinan Siri dalam Perspektif Hukum Islam, Hukum Positif dan Hak Asasi Manusia, (Jurnal Independen Vol.2 No.2), hal.56

32 Elimartati, Bunga Rampai Perkawinan di Indonesia (Batusangkar : STAIN Press, 2014, hal 149
} 
2. Penyelesaian kasus gugatan nikah siri, hanya bisa diselesaikan melalui hukum adat, dan tidak mempunyai kekuatan hukum

3. Pernikahan siri tidak termasuk perjanjian yang kuat (mitsaqan ghalizhan) karena tidak tercatat dan tidak dapat dipertanggungjawabkan secara hukum.

4. Apabila memiliki anak, maka anak tersebut tidak memiliki status yang jelas, tidak memperoleh akta kelahiran karena untuk memperoleh akta kelahiran, disyaratkan adanya akta nikah atau buku nikah.

5. Istri tidak memperoleh hak-haknya secara materi seperti dapat tunjangan istri bagi pegawai Negeri atau karyawan swasta, apabila suami meninggal tidak mendapat tunjangan kematian seperti asuransi, dana santunan dan lainlainnya.

6. Apabila terjadi perceraian atau kematian suami, maka istri tidak dapat menutut/memperoleh tunjangan perkawinan dari tunjangan pensiun suami, harta bersama, dan waris, serta hak-hak yang ditimbulkan karena kematian.

7. Perempuan yang di tinggal suaminya tidak bisa mengajukan khuluk dan tidak bisa menikah untuk berikutnya, karena tidak jelas statusnya. Dikatakan telah menikah tidak punya bukti, dikatakan masih gadis tetapi sudah janda malah banyak yang sudah punya anak.

\section{Analisa Penerapan SEMA No. 1 Tahun 2017 di PA Talu}

Setelah mempelajari putusan Pengadilan Agama Talu Nomor 121/Pdt.G/2018/PA TALU bahwa penetapan ikrar talak tidak bisa diucapkan sampai pihak pemohon membayarkan/melunasi semua yang terdapat dalam amar putusan, dan dipertegas oleh ketua Pengadilan Agama Talu YM Afrizal, S.Ag., M.Ag " jika sudah dicantumkan dalam amar, tidak ada eksekusi. Harus menunggu nafkah dibayarkan oleh suami. Jika lewat dari 6 bulan maka gugurlah putusan, sesuai dengan amar yang telah ditetapkan kemudian baru ikrar talak dibacakan. ${ }^{33}$

Bunyi amar dalam beberapa putusan perkara cerai talak di Pengadilan Agama hanya menyebutkan beberapa unsur. Diantaranya adalah unsur subjek yang membayar, obyek yang dibayar, jumlah dan wujud harta yang harus dibayarkan, serta jenis pembayaran. Amar putusan tersebut tidak memuat batas waktu pembayaran. Padahal di sisi lain yang erat kaitannya dengan hal itu, bahwasanya masa pengucapan ikrar talak tersebut dibatasi oleh waktu maksimal 6 bulan setelah ditetapkan hari sidang ikrar Majelis hakim akan menunda pelaksanaan ikrar talak bagi suami yang belum membayar nafkah kepada istri sampai 6 bulan. ${ }^{34}$ Berdasarkan Surat Edaran Mahkamah Agung (SEMA) Nomor 1 Tahun 2017, Tentang Pemberlakuan Rumusan Hasil Rapat Pleno Kamar Mahkamah Agung Tahun 2017 Sebagai Pedoman Pelaksanaan Tugas Bagi Pengadilan, maka majelis secara ex officio menghukum Tergugat

${ }^{33}$ Afrizal, S.Ag., M.Ag (Pada hari Kamis 22 November Ketua Pengadilan Agam Talu)

${ }^{34}$ Eka Susylawati , al-Ihkâm, Vo 1.8 No .2 De s emb e r 201 3: 374) 
Rekonvensi untuk membayar atau menyerahkan akibat perceraian berupa nafkah madhiyah, nafkah iddah sebelum pengucapan ikrar talak perkara nomor 121/Pdt.G/2018/PA TALU, bahwa berdasarkan pertimbanganpertimbangan tersebut majelis mengabulkan gugatan Penggugat untuk sebagian dan menolak untuk selebihnya;

Pelaksanaan Eksekusi Nafkah dalam pengucapan ikrar talak dilaksanakan oleh Pengadilan Agama Talu, dengan syarat adanya permohonan eksekusi dari pihak istri. Istri tidak melakukan permohonan eksekusi, karena biaya eksekusi lebih besar dari nafkah yang tidak dibayarkan oleh suami. Walaupun ada permohonan eksekusi dari pihak istri, tetapi benda maupun barang yang di eksekusi dari pihak suami tidak ada, maka pengadilan juga tidak bisa melaksanakan eksekusi. Walaupun ada suatu barang yang akan dieksekusi, tetapi barang/benda tersebut sumber penghidupan suami, maka eksekusi juga tidak bisa dilaksanakan ${ }^{35}$

Salah satu tujuan dibuat Undang-undang adalah untuk melindungi hak-hak isteri (perempuan) sebab terjadinya perceraian. Realitas hak seorang istri yang sudah dijamin oleh hukum materiil dan telah tegas dinyatakan dalam putusan pengadilan yang bersifat inkracht ${ }^{36}$, dan eksekutorial seringkali tidak ada artinya karena tidak dapat direalisasikan. Adanya peraturan perundang- undangan untuk melindungi hak istri diharapkan hak-hak isteri mendapatkan kepastian hukum, dan dapat dilaksanakan diterima oleh isteri sebagai akibat dari perceraian, namun kenyataanya hakhak istri seringkali terabaikan seperti perkara yang dibahas ini. Posisi istri sering berada dipihak yang lemah. Masalah ini sangat kental bias gendernya, perempuan diposisikan pihak yang lemah dan tidak punya daya serta upaya untuk mendapatkan hak-haknya. Tujuan SEMA Nomor 1 Tahun 2017 melindungi hak istri tidak tercapai diperkuat lagi hasil wawancara dengan ketua Pengadilan Agama Talu (Afrizal) Bahwasanya eksekusi amar putusan nafkah karena sudah dicantumkan dalam amar. kecuali istrinya ikhlas kemudian ikrar talak nya dibacakan. ${ }^{37}$

Temuan dalam penelitian ini ada tiga kondisi yang ketiganya tidak dapat memberikan keadilan terhadap hak-hak perempuan:

1. Suami tidak mengeksekusi putusan hakim tentang kewajiban nafkah yang ditetapkan oleh hakim Pengadilan Agama Talu, ikrar talak tidak dapat dilaksanakan, perkawinan tetap sah tetapi suami-istri tidak serumah lagi dan istri tidak pernah lagi mendapatkan nafkah.

Hakim Pengadilan Agama umumnya dalam perkara cerai talak selain memutus perkara pokoknya, juga mewajibkan untuk membayar nafkah pada istri

\footnotetext{
35 ( Wawancara dengan hakim)

36 (Eka Susylawati, dkk., al-Ihkâm)

${ }^{37}$ Afrizal, S.Ag., M.Ag (Pada hari Kamis 22 November ketua Pengadilan Agam Talu)
} 
dan anak. Hal ini ternyata berbeda dengan penerapan putusan, karena pemenuhan kewajiban suami tidak selamanya berjalan baik. Pada sebagian perkara pasca perceraian, istri tidak mendapatkan nafkah walaupun hal tersebut sudah diputus ${ }^{38}$. Setiap putusan pengadilan idealnya dipatuhi dan dilaksanakan secara sukarela oleh suami. Pemenuhan kewajiban memberi nafkah ini sangatlah tergantung pada i'tikat baik suami. Dalam praktik, apabila istri tidak memperoleh hak nafkahnya, dapat melaporkan hal tersebut ke pengadilan agama.untuk menuntut kewajiban suami memberi nafkah. Namun upaya tersebut pada umumnya tidak dapat langsung terealisasi, karena pengadilan hanyalah sebatas melakukan upaya persuasif, yakni memberikan teguran saja atau anjuran, tidak dapat dilakukan hak paksa. Kebanyakan suami merasa tidak bersalah saja bila tidak melaksanakan kewajibannya, akhirnya terpaksa istri berusaha memenuhi kebutuhan dirinya dan anaknya. Hukum acara yang berlaku memberikan kesempatan kepada istri permohonan eksekusi. Upaya eksekusi tersebut akan bermakna jika istri mengajukan permohonan upaya paksa ke pengadilan yang memutus perkara perceraian. Banyak sekali kasus pasca perceraian di mana istri tidak mendapatkan nafkah, walaupun hal tersebut sudah diputus oleh pengadilan. Hal inilah yang sering menimbulkan pertanyaan tentang nilai "kepastian hukum" putusan pengadilan agama.

Keinginan untuk memerkarakan kembali atas kelalaian suami terkendala oleh nilai nafkah yang tidak besar jika dibandingkan dengan biaya yang harus dikeluarkan untuk permohonan eksekusi. Akibatnya, mantan istri seringkali enggan untuk menuntut kewajiban pemenuhan hak-haknya sehingga hak hak tersebut tidak lebih "sebatas di atas kertas". Hal ini ironis karena hak seorang istri yang sudah dijamin oleh hukum materiil dan telah tegas dinyatakan dalam putusan pengadilan yang bersifat inkracht oleh pengadilan. dan eksekutorial seringkali tidak ada artinya karena tidak dapat direalisasikan

2. Bila istri ikhlas tidak mendapatkan hak-haknya setelah perceraian, maka hakim dapat menyaksikan ikrar talak suami akhirnya terjadi perceraian.

Membina sebuah rumah tangga memang bukan hanya untuk saling menguasai dan memiliki antara satu pihak dengan pihak yang lain. Karena pernikahan bukan hanya sebagai sarana pemuas nafsu seksual semata. Di dalamnya terdapat banyak tugas dan kewajiban yang besar bagi kedua belah pihak termasuk tanggung jawab ekonomi. ${ }^{39}$. dalam masyarakat banyak terjadi suami melaksanakan kewajiban memberi nafkah keluarga seadanya tidak melaksanakan dengan penuh rasa kesadaran hukum dan tanggung jawab sesuai dengan ketentuan yang berlaku merupakan kewajiban yang terukur bentuk, jenis

\footnotetext{
${ }^{38}$ Eka Susylawati, dkk, al Ihkam, Vo 1.8376 No .2 De s emb e r 2013

${ }^{39}$ Miftahur Rahman, An-Nawa, Jurnal Hukum Islam, Vol XX-Januari-Juni 2017
} 
dan kadarnya (muhaddad ). ${ }^{40}$ Berdasarkan kasus di atas terdapat permohonan cerai yang hakim sudah menerapkan aturan yang ada untuk membela hak istri. Tetapi kenyataan hak istri sering terabaikan. Dalam rumah tangga sering terjadi pertengkaran, penyebab utama adalah karena suami tidak bertanggung jawab, akhirnya istri tersiksa secara material dan spiritual. Kebutuhan keseharian tidak terpenuhi, dan batin tertekan, istri merana lahir dan batin. Solusi terbaik adalah mengikhlaskan suami mengucapkan ikrar talak dengan tidak mendapatkan hakhaknya. Kasus ini sejalan dengan penelitian yang dilakukan Eka Susilawati ${ }^{41}$ Pelaksanaan putusan nafkah istri pasca putusan cerai talak di Pengadilan Agama Pamekasan pada umumnya nafkah istri dibayar oleh suami sebelum pembacaan ikrar talak walaupun dengan nilai nafkah yang tidak relatif besar atau jauh apabila dibandingkan dengan tuntutan istri. Apabila suami tidak dapat memenuhi nafkah yang telah diputus oleh pengadilan agama, maka majelis hakim akan menunda pelaksanaan ikrar talak selama 6 bulan. Apabila dalam waktu 6 bulan tersebut suami tetap tidak menyatakan tidak mampu untuk membayar, maka pengadilan agama tetap akan memperkenankan suami untuk mengucapkan ikrar talak. Apabila hal ini terjadi, maka istri tidak akan memperoleh nafkah apapun dari suami.

Perempuan menjadi korban secara psikis dan materi dengan tidak adanya upaya untuk mencari keadilan (jalan buntu). Solusi yang terbaik adalah mengharapkan kesadaran suami akan tanggung jawabnya memberikan nafkah yang merupakan kewajibannya, Yang akan dipertanggungjawabkan di hadapan Allah SWT. Dalam kondisi tertentu perceraian menjadi solusi terbaik agar keduanya terlepas dari beban penderitaan lahir dan batin, tidak menimbulkan mafsadah yang lebih besar. tujuan SEMA untuk melindungi hak-hak istri kenyataannya tidak juga tercapai

\section{Suami melakukan nikah siri}

Berdasarkan hasil pengamatan peneliti dan hasil wawancara, dapat ketahui kondisi rumah tangga bapak (dan ibu.... tidak harmonis lagi. Sudah terjadi pisah ranjang selama 6 tahun 4 bulan sampai dengan saat permohonan talak ke Pengadilan Agama Talu. Sejak berpisah istri dan anak tidak pernah mendapatkan nafkah. Kondisi rumah tangganya tidak jelas status hukum, dikatakan cerai tidak punya bukti septentik, dikatakan rumah tangganya masih sah tetapi tidak serumah lagi. Kondisi semakin rumit sejak suami melakukan nikah siri. Keadaan ini menambah berat permasalahan dan menimbulkan masalah baru. Perempuan yang terabaikan secara hukum bertambah yakni perempuan yang menjadi istri siri. Istri siri tidak punya kekuatan hukum untuk menuntut haknya. Istri yang pertama saja yang mempunyai kepastian hukum tentang status dia sebagai istri tidak bisa mendapatkan haknya apalagi istri

40 Ibnu Rusy, Bidayah al-Mujtahid wa Nihayah al-Muqtashid ( Beirut: Dar Ihya'al-Kitab 'Arabiyah,tt, jilid II.hal.41. Wahbah al-Zuhaily, Figh Islam wa Adiilatuhu, ( Damaskus: Dar al-Fikr, 1989, jilid .VII,,hal.788

${ }^{41}$ Eka Susylawati, , al-Ihkâm, Vo 1. 8 No .2 De s emb e r 201 3: 374) 
dengan pernikahan siri. Istri pernikahan siri tidak punya aturan hukum untuk menuntut haknya.

pola ijtihad hakim dalam putusan bersifat pragmatis/menonton., hakim tidak berupaya melindungi hak perempuan, sehingga banyak putusan tentang nafkah tidak dapat direalisasikan, hakim hanya bersifat juru damai (hakam). Pemenuhan hak istri dan anak akibat putusnya perkawinan karena perceraian hasil penelitian menjelaskan bahwa Pemberian mut'ah yang layak kepada mantan istri berbeda-beda dikarenakan sesuai dengan kemampuan suami, majelis hakim menilai tentang kemampuan dari suami, tidak punya standar ukuran untuk menilai dan menentukan kadar mut'ah. Salah satu upaya yang perlu dilakukan terhadap pemenuhan nafkah istri pasca perceraian adanya dukungan dari berbagai pihak yang terkait terutama dari pihak keluarga suami -istri yang bersengketa. pihak terkait lainya seperti pengadilan agama yang memiliki kekuatan yuridis formal, Kementerian Agama dengan jajarannya,badan penasehat perkawinan.

\section{Kesimpulan}

Surat Edaran Mahkamah Agung No 1 Tahun 2017 bertujuan untuk memberikan perlindungan hukum bagi hak-hak perempuan pasca perceraian. Namun dalam pelaksanaannya hak-hak perempuan terabaikan. Istri sering di posisi yang terlemahkan. Menganalisis pelaksanaan eksekusi nafkah dalam pengucapan ikrar talak perkara Nomor 121/Pdt.G/2018/PA TALU yang tidak dijalankan oleh suami dapat disimpulkan tiga temuan dalam penelitian ini, yang ketiganya tidak dapat memberikan keadilan terhadap hak-hak perempuan: Pertama Suami tidak mengeksekusi putusan hakim tentang kewajiban nafkah yang ditetapkan oleh hakim Pengadilan Agama Talu, ikrar talak tidak dapat dilaksanakan, perkawinan tetap sah tetapi suami-istri tidak serumah lagi dan istri tidak pernah lagi mendapatkan nafkah. Kedua Bila istri ikhlas tidak mendapatkan hak-haknya setelah perceraian, maka hakim dapat menyaksikan ikrar talak suami akhirnya terjadi perceraian. Ketga Suami melakukan nikah siri. pola ijtihad hakim dalam putusan bersifat pragmatis/menonton., hakim tidak berupaya melindungi hak perempuan, sehingga banyak putusan tentang nafkah tidak dapat direalisasikan, hakim hanya bersifat juru damai (hakam). Pemenuhan hak istri dan anak akibat putusnya perkawinan karena perceraian hasil penelitian menjelaskan bahwa Pemberian mut'ah yang layak kepada mantan istri berbeda-beda dikarenakan sesuai dengan kemampuan suami, majelis hakim menilai tentang kemampuan dari suami.

\section{Daftar Pustaka}

Abdullah Aziz Muhammad Azzam dan Abdullah Wahab Sayeed Hawas, Ushratu wa Ahkamuhu fi altasti' al-Islami, diterjemahkan oleh Abdul Majid Khon, Fikih Munakahat, Jakarta, Amzah, 2009

Afrizal, S.Ag., M.Ag Pada hari Kamis 22 November ketua Pengadilan Agam Talu 
Anita Marwing, Perlindungan Hak-Hak Perempuan Pasca Perceraian (Studi Terhadap Putusan Pengadilan Agama Pelopo), Pelita: Jurnal of Soscial-Religiresearch Vol.1 No.1

Astsar riwayat Malik dan al-Bayhaqi, muatha'jilid 2

Enik Isnaini, Perkawinan Siri dalam Perspektif Hukum Islam, Hukum Positif dan Hak Asasi Manusia, Jurnal Independen Vol.2 No.2

Elimartati, Bunga Rampai Perkawinan di Indonesia Batusangkar : STAIN Press, 2014 Eka Susylawati dkk, al-Ihkâm, Vo 1.8 No .2 De s emb e r 201 3: 374

Fatima, Rabiatul Adawiyah, M.Rifqi, Pemenuhan Hak Istri Dan Anak Akibat Putusnya Perkawinan Karena Perceraian (Studi Kasus Di Pengadilan Agama Banjarmasin), (Jurnal Kewarganegaraan: Volume 4, Nomor 7, 2014

Firdaus al-Muqaddas, Pemikiran Satria Efendi M Zein dalam Pembaharuan Hukum Perdata Islam di Indonesia, Bogor: Landasan Ilmu, 2017

Irfan Islami, Perkawinan di Bawah Tangan (Kawin Sirri) dan Akibat Hukumnya, Adil: Jurnal Hukum, Vol.8 No.1

Jumni Nelli, Analisis Tentang Kewajiban Nafkah Keluarga dalam pemberlakuan harta Bersama, STAIN Curup Bengkulu: Jurnal Istimbat: Jurnal Hukum Islam vol. 2 No.1, 2017

Ibnu Ruysd, Bidayah al-Mujtahid wa Nihayah al-Muqtashid Beirut: Dar Ihya'al-Kitab 'Arabiyah, tt, jilid II

Miftahur Rahman, An-Nawa, Jurnal Hukum Islam, Vol XX-Januari-Juni 2017

Muhammad Ridwansyah, Nafkah Anak Luar kawin Menurut Konsep Hifzhu al-Nafs (Jural Yudisial Vol.8 No.! April 2015), hal.67,

M. Thahir Maloko, Nikah Sirri perspektif Hukum Islam Sipakalebbi' volume 2, 2014

Muslim bin al-Hajaj bin Muslim al-Qusyairy al-Naisabury, Shahih Muslim, (Cairo: Mathba ah al-B

Muhammad Rudi wijaya dan Anas Habibi Ritonga, Istri Sebagai Pencari Nafkah Utama dan Dampaknya dalam Keluarga Persfektif Hukum Islam, Padang Sidempuan: Fitrha Jurnal kajian Ilmu-ilmu Keislaman, Vol 04, 2018

Nunung Rodliyah, Akibat Hukum Perceraian Berdasarkan Undang-Undang Nomor 1 Tahun 1974 Tentang Perkawinan, Jurnal Keadilan: Volume 5 Nomor 1, 2014

Satria Efendi Problematika Hukum Keluarga Islam Kontemporer,Jakarta: Kencana, 2004

Salma, Elfia dan Afifah Djalal, Perlindunagn Hukum Bagi perempuan dan Anak (Analisis Putusan Hakim Tentang Nafkah Madhiyah pada Pengadilan Agama di Sumatera Barat, (Istimbath, jurnal of Islamic Law /Jurnal Hukum Islam vol 16 No. 16

Syaiful Hidayat (Jurnal tafaqquh: Jurnal Penelitian dan Kajian Islam Vol 6 Nomor 2, 2018)

Sunan Baihaqi bab izhar nikah jilid 7

Undang-Undang No 23 Tahun 2004 tentang Penghapusan KDRT Pasal 9 dan Pasal 49

ADHKI: Journal of Islamic Family Law 
Wahbah al-Zuhaily, Figh Islam wa Adiilatuhu, ( Damaskus: Dar al-Fikr, 1989, jilid .VII

PERMA Nomor 01 Tahun 2016

Kompilasi Hukum Islam

SEMA Nomor 01 Tahun 2017

Presiden Ri dan Menteri/Sektretaris Nehata RI, Undang-undang Republik Indonesia Nomor! Tahun 1974 Tentang Perkawinan Jakarta Republik Indonesia,1974 